\title{
RELATIONSHIP OF CHARACTERISTICS (AGE, SEX, LEVEL OF EDUCATION) WITH HYPERTENSION IN TRAINING OF HEALTHY FAMILY TRAINERS
}

\author{
Supriyono ${ }^{1)}$ \\ Widyaiswara Associate Expert, Central Java Regional Human Resource Development Agency, \\ ${ }^{1)}$ Setiabudi No. 201 A Street Semarang, E-mail: supriyonontr@yahoo.co.id \\ Agus Andriyanto ${ }^{2)}$ \\ 2).Widyaiswara Young Expert, Central Java Regional Human Resource Development Agency, \\ Setiabudi No. 201 A Street Semarang, \\ E-mail: agusandripkl@gmail.com
}

\begin{abstract}
:
Based on the results of the Basic Health Research (Riskesdas) in 2013, the prevalence of hypertension is still high at $25.8 \%$, so hypertension is still one of the public health problems in Indonesia. This study aims to determine the relationship of characteristics (age, gender, and level of education) with hypertension in participants of the Training of Healthy Family Trainers. This type of research is cross-sectional with a sample of 30 people. Data collection by interview and blood pressure examination. Interviews were conducted to find out data about respondents' characteristics which included age, gender and level of education. Whereas for blood pressure measurements are carried out with sphygmomanometer. Data analysis using statistical test Spearman Rank Correlation Test. Based on the results of blood pressure measurements obtained the following results, blood pressure in the normal category $=23.30 \%$, prehypertension $=53.3 \%$, hypertension first degree $=16.7 \%$, second degree hypertension $=3.3 \%$ and severe hypertension $=6.7 \%$. From the statistical test, the results of $\mathrm{p}=\mathrm{age}=0.961 \mathrm{p}$ sex $=0.172 \mathrm{p}=$ education level $=$ 0.679 ( $p>0.05)$. Age, gender and education are not the sole factors causing hypertension. Therefore, to reduce hypertension, it is necessary to apply clean and healthy living behaviours There is no relationship between age, sex and level of education with hypertension. Providing a health examination room in the form of a health clinic, which is equipped with human resources (doctors, nurses, midwives, and nutritionists)
\end{abstract}

Keywords: Hypertension, Age, Gender, Education Level, Rank Spearman Correlation

\section{INTRODUCTION}

Based on the results of Riskesdas (Basic Health Research) in 2013, the prevalence of hypertension in Indonesia is still quite high at $25.8 \%$, so hypertension is stated as one of the public health problems in Indonesia. If hypertension is not well controlled, it can cause various complications such as heart disease, stroke and kidney. During this time hypertension also did not get serious attention, especially on the training participants, so often found when the training 
took place suddenly there were participants who experienced disorders such as high blood pressure. Research on the relationship between age, sex and education level with hypertension in training participants has not been much studied. Therefore, it is necessary to further study the relationship (age, sex, and education level) with hypertension through a study.

\section{MATERIAL AND METHODS}

This research is an observational study with a cross-sectional design. Data collection methods used include observation, interviews, and measurement of blood pressure. Population and sample are all 30 healthy respondents training participants. Data is processed using descriptive statistics in the form of frequency distribution and percentage. Normality test is used to find out whether the data is normally distributed or not normal. From the test results obtained that all data is not normally distributed. Therefore the Spearman rank correlation test is used

\section{RESULTS AND DISCUSSION}

\section{Characteristics of respondents}

The average age of respondents was 44 years, with a standard deviation of 6.35 years. The age of the youngest respondent is 31 years and the oldest is 54 years. With the distribution of age dominated by productive age (41-45) in the amount of $36.70 \%$. Respondent's gender is dominated by female participants that are equal to $63.30 \%$. The education level of respondents is strata one and two, which is equal to $50.00 \%$. More can be on graphs 1, 2 and 3

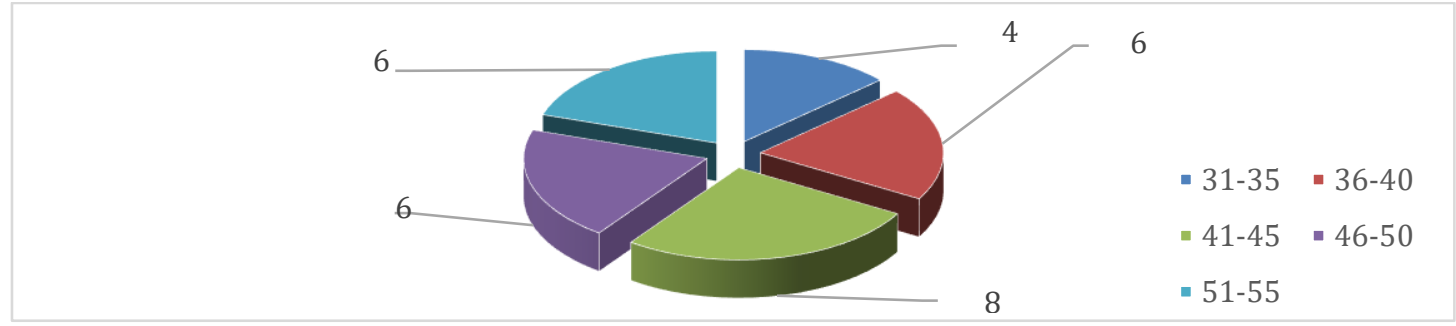

Graph 1 : Age of respondents

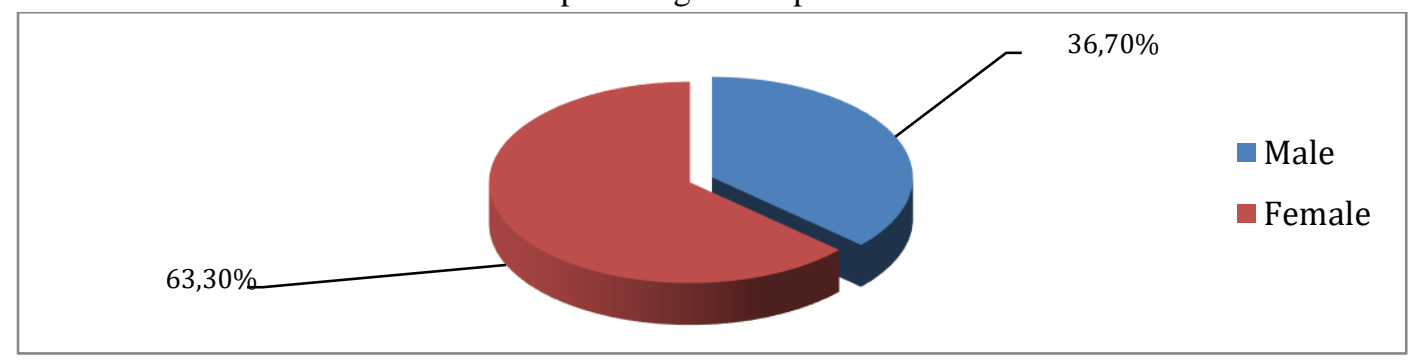

Graph 2 : Gender of the respondents 


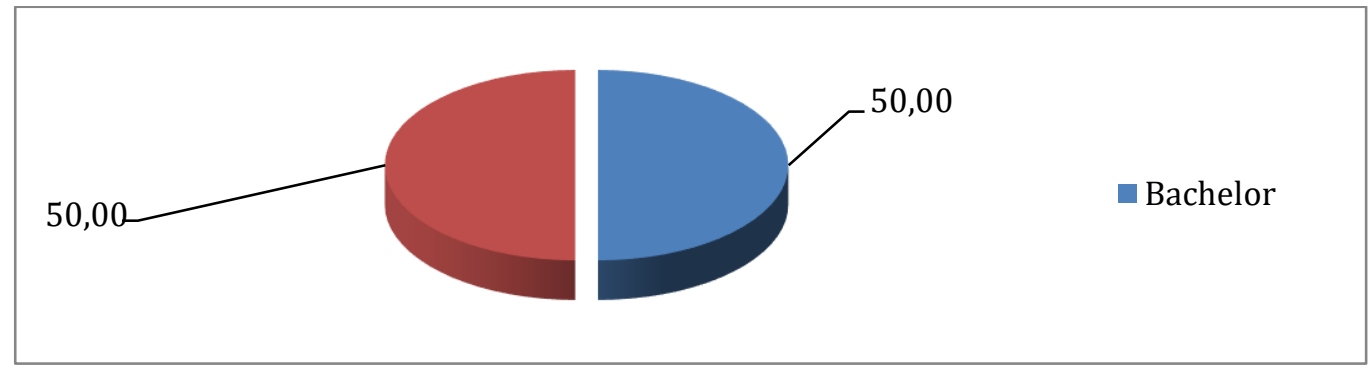

Graph 3 : Education level of the respondents

\section{Blood pressure}

Based on blood pressure measurement results obtained as follows, blood pressure in the normal category $=23.30 \%$, prehypertension $=53.3 \%$, first degree hypertension $=16.7 \%$, second degree hypertension $=3.3 \%$ and severe hypertension $=67 \%$. Can be seen in graph 4

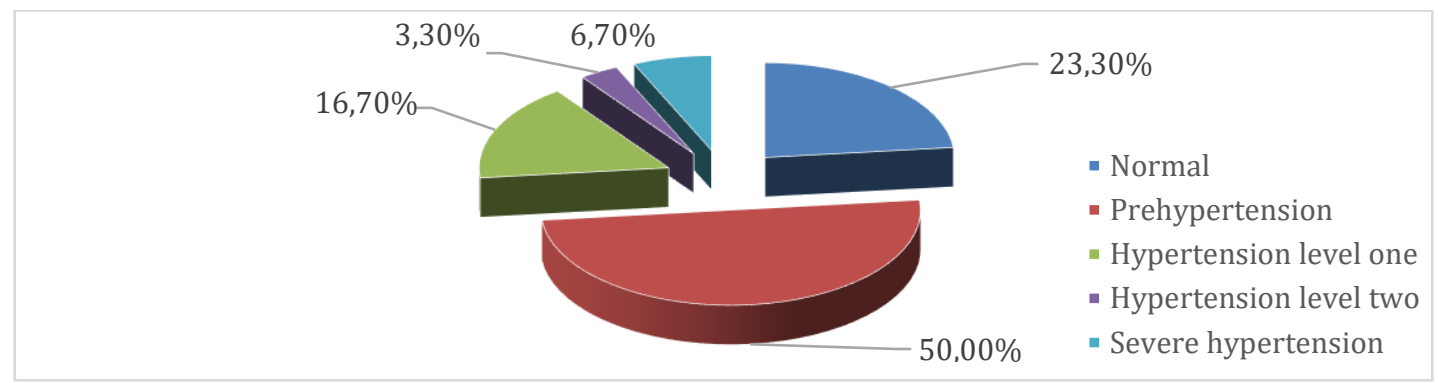

Graph 4 : Distribution of blood pressure

The highest systolic blood pressure is $120 \mathrm{mmHg}$ and the lowest diastolic blood pressure is $60 \mathrm{mmHg}$. Furthermore, the results of measurements based on systolic and diastolic blood pressure are listed in table 1

Table 1: Distribution of sistolyc and diastolic of blood pressure

\begin{tabular}{ccccc}
\hline Blood & \multicolumn{3}{c}{ Systolic } & \multicolumn{2}{c}{ Diastolic } \\
\cline { 2 - 5 } pressure & $\mathrm{n}$ & Persentase & $\mathrm{n}$ & Persentase \\
\hline Normal & 7 & 23,30 & 22 & 73,30 \\
Hypertension & 23 & 76,70 & 8 & 26,70 \\
\hline
\end{tabular}

Source : primary data, 2017

According to table 1, systolic blood pressure in the normal category is $23.30 \%$, and hypertension is $76.70 \%$, with a mean of $135.93 \mathrm{mmHg}$, and a standard deviation (SD) of 21.552. The highest systolic blood pressure is $206 \mathrm{mmHg}$ and the lowest is $109 \mathrm{mmHg}$. As for the diastolic blood pressure in the normal category of $73.30 \%$, while hypertension is $26.70 \%$, with a mean of $83.43 \mathrm{mmHg}$, with a standard deviation (SD) of 10.925 , with the highest diastolic blood pressure of $120 \mathrm{mmHg}$ and the lowest $60 \mathrm{mmHg}$. Thus systolic blood pressure has a higher distribution than diastolic blood pressure 
3. Relationship between age, gender, education level with hypertension

Next in tables 2, 3 and 4, the relationship between age, gender and education level with hypertension

Table 2: Correlationship of age with blood pressure

\begin{tabular}{|c|c|c|c|c|c|c|c|}
\hline \multirow{3}{*}{ Age } & \multicolumn{4}{|c|}{ Category } & & & \multirow{3}{*}{$\mathrm{p}$} \\
\hline & \multicolumn{2}{|c|}{ Normal } & \multicolumn{2}{|c|}{ Hypertension } & \multicolumn{2}{|c|}{ Total } & \\
\hline & $\mathrm{n}$ & $\%$ & $\mathrm{n}$ & $\%$ & $\mathrm{n}$ & $\%$ & \\
\hline $31-35$ & 1 & 25,00 & 3 & 75,00 & 4 & 100,00 & $0,961 *)$ \\
\hline $36-40$ & 1 & 16,70 & 5 & 83,30 & 6 & 100,00 & $0,961 *)$ \\
\hline $41-45$ & 2 & 25,00 & 6 & 75,00 & 8 & 100,00 & $0,961 *)$ \\
\hline $46-50$ & 2 & 33,30 & 4 & 66,70 & 6 & 100,00 & $0,961 *)$ \\
\hline $51-55$ & 1 & 16,70 & 5 & 83,30 & 6 & 100,00 & $0,961 *)$ \\
\hline
\end{tabular}

*) Spearman Rank Correlation Test, from primary data, 2017

Table 3 : Relationship of gender with blood pressure

\begin{tabular}{|c|c|c|c|c|c|c|c|}
\hline \multirow{3}{*}{ Gender } & \multicolumn{4}{|c|}{ Blood of pressure } & \multirow{2}{*}{\multicolumn{2}{|c|}{ Jumlah }} & \multirow{3}{*}{$\mathrm{p}$} \\
\hline & \multicolumn{2}{|c|}{ Normal } & \multicolumn{2}{|c|}{ Hypertension } & & & \\
\hline & $\mathrm{n}$ & $\%$ & $\mathrm{n}$ & $\%$ & $\mathrm{n}$ & $\%$ & \\
\hline Male & 1 & 10,10 & 10 & 90,90 & 11 & 100,00 & $0,172 *)$ \\
\hline Female & 6 & 31,60 & 13 & 68,40 & 19 & 100,00 & $0,172 *)$ \\
\hline
\end{tabular}

*) Spearman Rank Correlation Test, from primary data, 2017

Table 4: Relationship of level education with blood pressure

\begin{tabular}{|c|c|c|c|c|c|c|c|}
\hline \multirow{3}{*}{$\begin{array}{c}\text { Level } \\
\text { of } \\
\text { education }\end{array}$} & \multicolumn{4}{|c|}{ Blood of pressure } & \multirow{2}{*}{\multicolumn{2}{|c|}{ Total }} & \multirow{3}{*}{$\mathrm{p}$} \\
\hline & \multicolumn{2}{|c|}{ Normal } & \multicolumn{2}{|c|}{ Hypertension } & & & \\
\hline & $\mathrm{n}$ & $\%$ & $\mathrm{n}$ & $\%$ & $\mathrm{n}$ & $\%$ & \\
\hline Bachelor /Diploma four & 4 & 26,70 & 11 & 73,70 & 15 & 100,00 & $0,679 *)$ \\
\hline Postgraduate & 3 & 46,90 & 12 & 54,10 & 15 & 100,00 & $0,679 *)$ \\
\hline
\end{tabular}

*) Spearman Rank Correlation Test, from primary data, 2017

In this research, the hypothesis to be tested is "There are Relationship Characteristics (age, sex and education level) with hypertension of the Training of Trainers of Healthy Families" which is the original hypothesis (Ha). While for the purposes to test the hypothesis, the hypothesis is changed to zero hypotheses (Ho) so that it becomes "No Relationship Characteristics (age, sex and education level) with hypertension training Training of Healthy Family Trainers. Testing is done using the Spearman Rank Correlation Test

Based on the Spearman Rank Test, the results obtained (p) age, gender and education level are $0.961,0.172$ and 0.679 ( $p>0.05$ ), then Ho is accepted, so there is no relationship between age, sex, education level with hypertension

The absence of an age relationship with hypertension is not by accordance which states that there is a tendency to increase in prevalence according to age. In this case, the age factor is not the only originator of the occurrence of hypertension, because it was allegedly there are other factors such as a person's lifestyle such as consuming unbalanced food, less consumption of vegetables and fruit

With the habit of consuming vegetables and fruit in sufficient quantities, it is expected to reduce a person's blood pressure. Many epidemiological studies by health and nutrition experts 
related to the role of vegetables and fruits in lowering blood pressure. Besides the wrong eating habits such as eating a lot of fast food, fast food, junk food and other preserved foods also become one of the triggers for hypertension. So the habit of eating vegetables and fruits need to be instilled from an early age

Furthermore, there is no significant relationship between sex with hypertension. This study has similarities with the results of research conducted that gender is not the only cause of hypertension. Because there is no relationship is due to various factors including stress and hormonal factors

Someone who is experiencing stress will be prone to hypertension. This can be seen in plain view, that with increasing stress a person's pulse will increase. This situation is one of the triggers of hypertension when viewed from the point of stress. This state of stress can be seen in a person's daily life. In addition to hormonal factors is also one of the triggers for high blood pressure. In general, women have lower blood pressure compared to men, because women, especially those not yet menopausal, are protected by the hormone estrogen. The role of this estrogen in other body metabolism is in increasing levels of High-Density Lipoprotein (HDL), so that blood pressure in women tends to below

There is no relationship between hypertension and education level, also shown in this study is between the level of education with hypertension. The absence of this relationship is in line with research because the level of education will affect one's lifestyle such as smoking, alcohol consumption, food intake, physical activity, and stress. Thus to control hypertension is to always apply a clean and healthy lifestyle in everyday life.

These habits include always eating a balanced diet, not smoking, regular exercise, controlling stress and getting enough rest which are all reflected in an ingenious lifestyle that includes health checks, get rid of cigarette smoke, diligently exercising, balanced diet, adequate rest and managing stress. This movement is summarized in the Community Movement. To eat fish, vegetables, fruit, and exercise. All of which lead to a healthy life without stress.

\section{CONCLUSION}

As many as $76.70 \%$ of trainees suffer from hypertension which is divided into prehypertension $=53.3 \%$, first degree hypertension $=16.7 \%$, second degree hypertension $=3.3 \%$ and severe hypertension $=6.7 \%$. Age, sex, education level were not significantly related to the incidence of hypertension in the Training of Trainer of Healthy Family Trainers at Batam National Health Training Center 


\section{REFERENCES}

1. Agusmita, 2018, Cara Menulis Daftar Pustaka Dari Internet, http://cara menulis buku.com/caramenulis-daftar-pustaka-dari-internet.htm, diakses tanggal 10-1-2018, 13.15 wib,

2. Anggraini, dkk. 2009. Faktor- Faktor yang Berhubungan dengan Kejadian Hipertensi Pada Pasien yang berobat di Poliklinik Dewasa Puskesmas Bangkinang, Periode Januari 2009, Pekanbaru https://yayanakhyar.files.wordpress.com, diakses 18 Juni 2017, 10.12 WIB

3. Badan litbangkes Republik Indonesia, 2013, Riset Kesehatan Dasar, http://depkes.go.id/downloads/riskesdas2013, diakses 10-9-2017, 08.35 wib

4. Fitriani Nur, Neffrety Nilamsari, 2017, Faktor-faktor Yang Berhubungan dengan Tekanan Darah pada Pekerja Shift dan Pekerja Non-Shift di PT.X Gresik, Journal of Industrial Hygiene and Occupational Health Volume 2 No. 1 Oktober 2017, https://ejournal.unida.gontor.ac.id/index.php, http://dx.doi.org, diakses 12-1-2018, 08.45 wib

5. Fitriani Nur, Neffrety Nilamsari, 2017 dalam Anggara, FHD., dan Prayitno, N.2013. FaktorFaktor Yang Berhubungan Dengan Tekanan Darah Di Puskesmas Telaga Murni, Cikarang Barat Tahun 2012 . Program Studi S1 Kesehatan Masyarakat STIKes MH. Thamrin. Jurnal Ilmiah Kesehatan. 5(1):20-25, Jakarta,

6. Gracilaria Puspa Sari, Marek Samekto, Mateus Sakundarno Adi. "Faktor-Faktor Yang Berpengaruh Terhadap Terjadinya Hipertensi Pada Penderita Diabetes Melitus Tipe Ii (Studi di Wilayah Puskesmas Kabupaten Pati)", Jurnal Litbang: Media Informasi Penelitian, Pengembangan dan IPTEK, 2017

7. Kementerian Kesehatan Republik Indonesia. 2014, Infodatin. Hipertensi. Pusdatin, Jakarta

8. Kementerian Kesehatan Republik Indonesia, 2016, Modul Keluarga Sehat, Jakarta

9. Muniroh Lailatul, et al, 2007, Pengaruh Pemberian Jus Buah Belimbing dan Mentimun terhadap Penurunan Tekanan darah sistolik dan Diastolik pada penderita Hipertensi, Universitas AirlanggaSurabaya,https://www.researchgate_diakses 22 Juni 2017, 10.15 wib

10. Wahyuningsih dan Endri Astuti, 2008, Faktor Yang Mempengaruhi Hipertensi pada Usia Lanjut, Jurnal Ners dan Kebidanan Indonesia, Yogyakarta, file:///C:/Users/Acer/Downloads/9-15-4PB.pdf, diakses pada 11-9-2017, 09.30 wib 